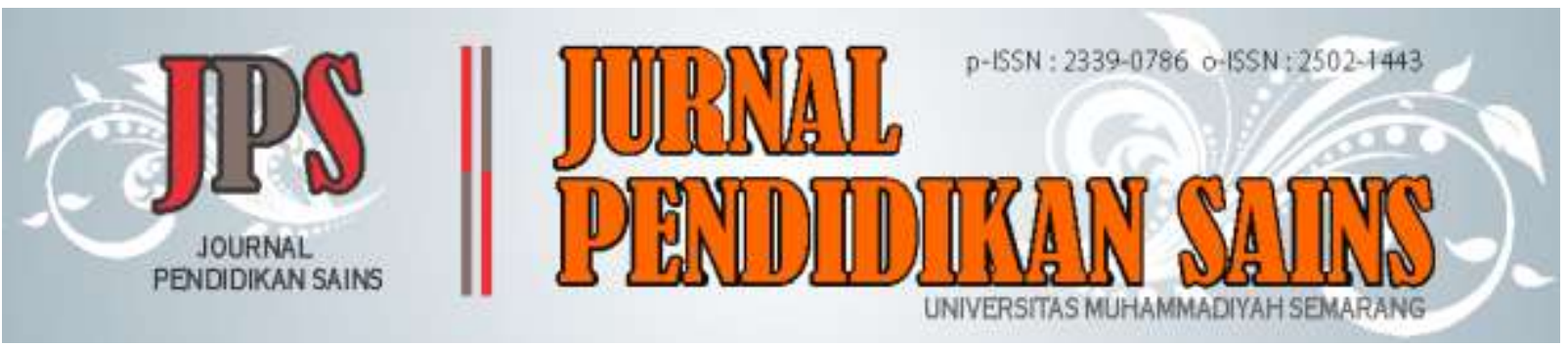

\title{
Need Analysis for Developing a STEM-Based Student Worksheet Application
}

\author{
Fadillah Rahmayani $^{\text {a, 1,* }}$, Menza Hendri ${ }^{\text {b,2 }}$, Dian Pertiwi Rasmi ${ }^{\text {b,3 }}$

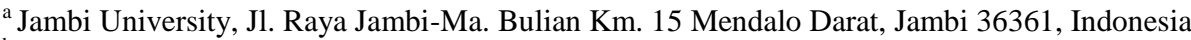 \\ ${ }^{\mathrm{b}}$ Jambi University, Jl. Raya Jambi-Ma. Bulian Km. 15 Mendalo Darat, Jambi 36361, Indonesia \\ ' Jambi University, Jl. Raya Jambi-Ma. Bulian Km. 15 Mendalo Darat, Jambi 36361, Indonesia \\ ${ }^{1}$ fadillahrahmayani82@gmail.com, ${ }^{2}$ menzahendri@unja.ac.id, ${ }^{3}$ dianrasmi@unja.ac.id
}

\begin{tabular}{ll}
\hline \multicolumn{2}{l}{ Article history } \\
\hline Submission & $: 2021-02-28$ \\
Revised & $: 2021-04-20$ \\
Accepted & $: 2021-08-03$
\end{tabular}

Keyword

Need Analysis

STEM-learning

Student Worksheet

Study Application

\begin{abstract}
This study aims to analyze and determine the needs of teachers and students for learning media development in the form of a STEM-based student worksheet application. Data was obtained through observation, interviews, and student learning style questionnaires given to teachers and students of SMA N 1 Muaro Jambi. Teachers need exciting and interactive learning media that can attract students' interest. In contrast, students need learning media that combines all aspects of visual, auditory, and kinesthetic learning styles obtained from questionnaires. Students have visual, kinesthetic, and auditory learning styles with a percentage of $58.3 \%, 58.3 \%$, and $52.8 \%$. So Researchers will develop student worksheets in digital form that refer to the results of the learning style analysis. Products produced are in the form of android and based on STEM. This study shows the results of the needs analysis in developing STEM-based applications,
\end{abstract}

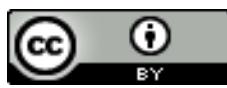

This work is licensed under a Creative Commons Attribution 4.0 International

\section{INTRODUCTION}

At this time, we have entered the digital era known as the industrial era 4.0, where there is much competition, including competition in terms of human resources. Walidin (2016) states that in terms of human resource development, education has a strategic value and essential role as an investment in the future. In this era, movements that humans initially carried out are slowly being shifted by digital technology. In order to remain competitive in this global competition, each person is required to have superior competencies and skills. Therefore, education or knowledge is needed that can become a background for competitiveness for each human being.

Education is vital and needed in human life because a person's life will be more focused on education. This is also in line with Sudarsana (2016) that education is an effort to empower humans to become whole human beings to actualize self. In addition, education can produce students and prospective educators who excel in various fields, including forming someone who is literate towards science and can relate it to everyday life. Science plays an essential role in producing students who understand natural science and can take the initiative in responding to issues that occur as a result of technological developments. This is in line with Gherardini, n.d, (2016) that science plays a vital role in preparing students who can think critically, creatively, logically, and take the initiative in responding to 
issues caused by the development of science and technology. Therefore, in order to keep abreast of developments in technology, understanding science is essential.

One of the government policies in education is the implementation of the 2013 curriculum. The 2013 curriculum provides students with a direct learning experience following the background, characteristics, and initial abilities. However, in reality, learning that should be student-centered is not fully enforced; this is because there are still some teachers who still teach students with conventional learning methods where learning places students as objects and teachers as subjects.

Rahmayani (2019) argues that education includes various branches of science, one of which is physics, which studies changes in natural conditions and the interactions that occur in them. It is also in line with what was stated by Karyawan (2019) that in broad terms, physics is the science of nature, namely physics studies natural phenomena that are not living or matter in space and time. According to Pentury et al. (2019), learning physics in high schools aims to develop attitudes, knowledge, and skills through mastery of physics concepts and principles to be applied in everyday life.

For students to relate the knowledge they acquire to real life, one of them is by using STEM (Science, Technology, Engineering, and Mathematics) approaches. STEM (Science, Technology, Engineering, and Mathematics) education is currently a science learning option that can uphold a generation capable of overcoming the challenging 21st century. According to Anggraini \& Huzaifah (2017), STEM is an approach that integrates and links several STEM subjects to create learning based on problems of everyday life. So that applying the STEM approach can train students to apply the knowledge learned in class with phenomena. that happened in the real world.

Recent reforms in science education are the push for STEM education, emphasizing STEM projects and programs to enable students to connect with the STEM field (Anggraini \& Huzaifah (2017). Sanders (2009) describes STEM as an integrative approach, exploring teaching and learning between two or more STEM subject areas or between STEM subjects and other school subjects.

The teaching materials used by the teacher affect the learning outcomes of students. Therefore we need teaching material that supports the learning process, one of which is the Student Worksheet. Worksheets are practical, valuable, and economical material for use in educational activities. The worksheets have been used in educational activities for centuries. Rahmiati and Pianda (2018) suggest that student worksheets are assignment sheets that students must work on, containing instructions and steps for completing tasks. The task contains problems or descriptions that lead students to gain knowledge and build work in groups.

Lee (2014)argues that Student Worksheets can be helpful in many ways in academic achievement. For example, as support for textbooks, student worksheets can also function as information enhancers. In addition, students can also use worksheets to fill in the blanks, where they can be used to expand knowledge. These student worksheets can also be filled with various material and questions that interest students when paired with the proper teaching method.

In addition, with the development of technology, students already have an Android or smartphone that is used in everyday life. Robika Alkadri and Yurnetti (2017) suggest that Android mobile learning is more effective than computers because students can access lessons anywhere and anytime without being bound by space and time. Nadiroh \& Wibowo (2018) also explain that the Android-based Student Activity Sheet is more accessible to students anywhere and anytime and does not require much space to install this application. Users can choose menus according to learning needs in the learning process or independently by students.

Based on the observations at SMA N 1, Muoaro Jambi knows that students sometimes use the student worksheet, but that worksheet did not use based on STEM. They are never using an android application, too, and just by the book from school. From the observations, students also have visual, kinesthetic, and auditorium learning styles with a percentage of $58.3 \%, 58.3 \%$, and $52.8 \%$. So that Researchers will develop student worksheets in digital form that refer to the results of the learning style analysis; this need is also strengthened by interviews that have been conducted with teachers of SMA N 1 Muaro Jambi. This study aimed to analyze and explore the needs of teachers and students for the development of learning media in the form of STEM-based student worksheet applications that are attractive, easy to use, and valuable for students and teachers alike.

\section{METHOD}


This study conducted a research study of the needs analysis of students and teachers of SMA N 1 Muaro Jambi. There are several activities in this needs analysis: material analysis, literature analysis, student analysis, and learning environment analysis. The material analysis aims to identify competencies or skills that students must learn, including KI, KD, material, assessment instruments, and assessment indicators Endriani et al., (2018). Researchers analyzed KI, KD, and indicators which became references in developing products. At the Literature Analysis stage, the researcher completes a literature review and analyzes relevant research to support the product development process.

Next is to analyze students. The student analysis stage aims to determine the problems faced during the learning process. At this stage, observation activities are carried out when the learning takes place. This observation aims to analyze students or obtain information about learning tools, learning methods, and student attitudes when learning takes place. From an interview with a student, we know that In that school using curriculum 2013, They are using a book for study physics and sometimes do an experiment practice. We also know that they are never using an Android Application during the study. In addition, interviews were also conducted with Physics Subject teachers to analyze the needs of teachers and students in learning.

Furthermore, at this stage, an analysis of the learning styles of students is also carried out. In this instrument, there are 42 questions divided into three parts of the questionnaire; there are 13 questions on visual learning styles, 14 questions on auditory learning styles, and 15 questions on kinesthetic learning styles. The questionnaire data were measured using a Likert scale with the answer choices: always, often, never, and very never. The Likert scale score used is a scale of 4 , which is described in Table 1.

Table 1. Likert Scale Score Expert Validation Sheet

\begin{tabular}{cc}
\hline Information & Score \\
\hline Very never & 1 \\
\hline Never & 2 \\
\hline Often & 3 \\
\hline Always & 4 \\
\hline
\end{tabular}

Furthermore, to classify the data the following equation is used:

With: $\quad$ Max $=$ Maximum Value

$$
\text { Interval }=\frac{\text { Max }- \text { Min }}{\text { Jumlah } \text { kelas }}(1)
$$

Min $=$ Minimum Value

By using equation (1), the learning style will be classification. Then categorized into the range of intervals shown in Table 2 below:

Table 2. Classification of Expert Validation Sheet Scores

\begin{tabular}{cc}
\hline Score Interval & Score Category \\
\hline $1.00-1.75$ & Very never \\
\hline $1.76-2.50$ & Never \\
\hline $2.51-3.25$ & Often \\
\hline $3.26-4.00$ & Always \\
\hline
\end{tabular}

Research procedures can be seen in Figure 1. 


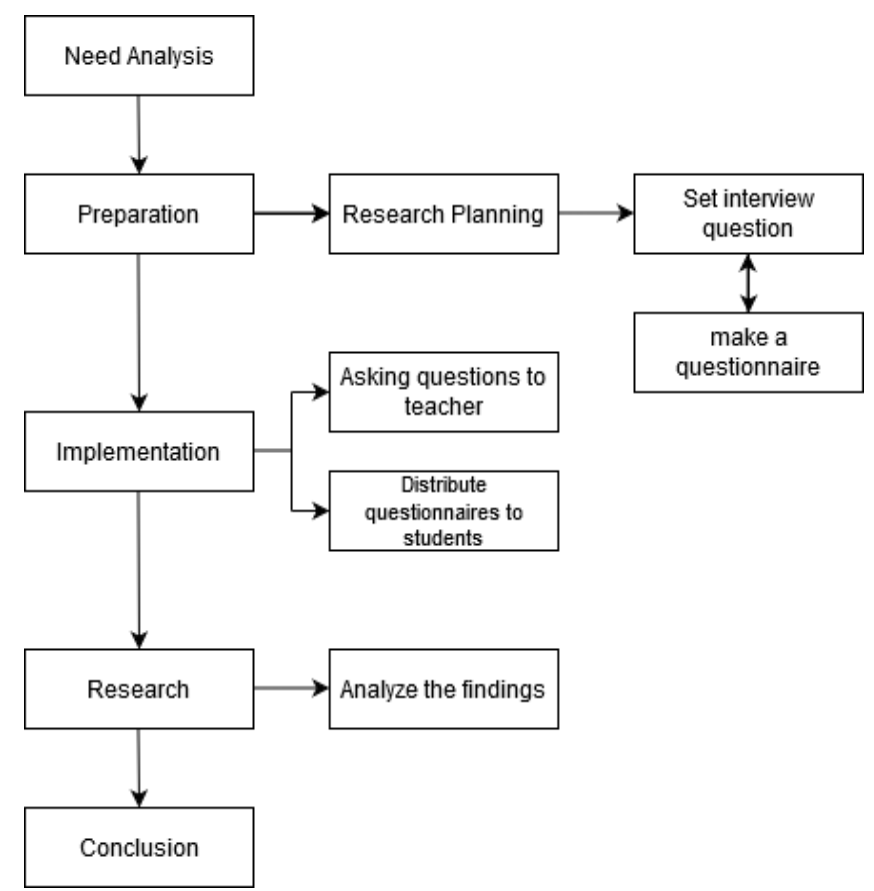

Figure 1. Research Procedures

\section{RESULTS AND DISCUSSION}

Based on the results of interviews conducted with the Physics Learning Teacher regarding the need for teaching materials and the importance of developing this product, it can be seen in table 3 .

Table 3. Teacher Response Needs Analysis

\begin{tabular}{|c|c|c|}
\hline No. & Question & Answer \\
\hline 1 & $\begin{array}{l}\text { What curriculum is used in this } \\
\text { school? }\end{array}$ & This school uses the 2013 Curriculum \\
\hline 2 & $\begin{array}{l}\text { How to use media in learning } \\
\text { activities }\end{array}$ & $\begin{array}{l}\text { The use of media during the learning process is } \\
\text { usually the media used in textbooks from the } \\
\text { publisher and PPT (PowerPoint). }\end{array}$ \\
\hline 3 & $\begin{array}{c}\text { What study are books used in } \\
\text { learning? }\end{array}$ & Physics study book for grade $\mathrm{X}$ high school \\
\hline 4 & $\begin{array}{l}\text { How many times have you done } \\
\text { practicum in learning? And in } \\
\text { what material? }\end{array}$ & $\begin{array}{l}\text { Practicum in learning is adjusted to the needs of } \\
\text { KI KD in the syllabus, but sometimes practicum } \\
\text { is challenging to do with limited time }\end{array}$ \\
\hline 5 & $\begin{array}{l}\text { During the learning process, do } \\
\text { you use supporting media such } \\
\text { as Student Worksheets? }\end{array}$ & Yes, we do \\
\hline 6 & $\begin{array}{l}\text { How do students use the } \\
\text { worksheets? }\end{array}$ & Student worksheets in printed form \\
\hline 7 & $\begin{array}{l}\text { how to make student worksheets } \\
\text { that are used? Where is the } \\
\text { source of the } \\
\text { experiment/material used? Made } \\
\text { by you or from the internet or } \\
\text { student worksheets published by } \\
\text { publishers. }\end{array}$ & $\begin{array}{c}\text { The source is from the internet, made according } \\
\text { to the title of the material needed }\end{array}$ \\
\hline 8 & does he have already know about & Knowing, but never applied. So far, Student \\
\hline
\end{tabular}




\begin{tabular}{|c|c|c|}
\hline & $\begin{array}{l}\text { STEM? Have you ever used } \\
\text { STEM-based student worksheets } \\
\text { so far? }\end{array}$ & $\begin{array}{l}\text { Worksheets are taken from the internet in the } \\
\text { form of theoretical testing based on KI KD }\end{array}$ \\
\hline 9 & $\begin{array}{l}\text { how to use technology in } \\
\text { learning activities? Like the use } \\
\text { of an android smartphone, for } \\
\text { example? }\end{array}$ & $\begin{array}{l}\text { Students may bring cellphones in learning to } \\
\text { assist in learning; for example, they need } \\
\text { information from the internet while studying. }\end{array}$ \\
\hline 10 & $\begin{array}{l}\text { Has he ever used a student } \\
\text { worksheet in the form of an } \\
\text { Android application? }\end{array}$ & Has never been \\
\hline 11 & $\begin{array}{l}\text { does he interested in developing } \\
\text { learning support media such as } \\
\text { android-based STEM student } \\
\text { worksheets? Why? }\end{array}$ & $\begin{array}{l}\text { Very interested if it is held so that the cellphones } \\
\text { carried by students in learning can be more } \\
\text { practical and are made based on STEM that also } \\
\text { seems to increase progress in learning }\end{array}$ \\
\hline 12 & $\begin{array}{l}\text { According to him, what kind of } \\
\text { learning process can arouse } \\
\text { enthusiasm for learning? }\end{array}$ & $\begin{array}{l}\text { The learning process that inspires enthusiasm is } \\
\text { that learning must be enjoyable; there is a } \\
\text { doctrine that physics is complicated, so it also } \\
\text { requires learning media that is attractive and } \\
\text { provokes student interest. }\end{array}$ \\
\hline 13 & $\begin{array}{l}\text { what about student learning } \\
\text { outcomes so far? Especially in } \\
\text { learning that uses student } \\
\text { worksheets in learning. }\end{array}$ & $\begin{array}{l}\text { So far, student learning outcomes in using these } \\
\text { student worksheets will result in better learning } \\
\text { outcomes because student learning becomes } \\
\text { regular. After all, there are steps in it. }\end{array}$ \\
\hline
\end{tabular}

Based on the interview results, it shows that the school has implemented the 2013 curriculum where based on the Peraturan Menteri Pendidikan dan Kebudayaan (Permendikbud) No. 81 A about curriculum implementation, explains that learning in the 2013 Curriculum uses a scientific approach and is student-centered. According to students ' backgrounds, characteristics, and initial abilities, the 2013 curriculum allows students to have direct learning experiences (learned curriculum). So that in this case, it is essential to have student-centered learning not only from the teacher who gives lectures or with conventional methods. In this case, it can be said that the implementation of the practicum is essential so that students can find answers and find out learning material from experiments and direct experience.

The teaching materials used by the teacher are in the form of textbooks, worksheets, and sometimes also use power points, and it is permissible to use cellphones to search for material on the internet. Teaching materials or learning media that students use must also be made as attractive as possible to become excited about learning and tend not to get bored. Therefore, interactive learning media can also be used to increase insight and understanding of concepts and student learning motivation. Santana et al. (2019) suggest that interactive learning media can positively respond to student understanding of learning material. Interactive learning materials also usually tend to be teaching materials that use information technology assistance.

The teacher also uses supporting media such as student worksheets, but the student worksheets are sourced from experiments on the internet. The Student Worksheet also used contains Exercise Questions and theoretical testing only; meanwhile, in the 21 st-century, students are also required to be skilled in using technology. In terms of the use of technology, Educators also said that most students had an Android smartphone that could be used if needed during learning for the sake of learning. So far, educators have never used Android-based Student Worksheets or STEM-based Student Worksheets.

In addition to conducting interviews with teachers, questionnaires for student learning styles were also carried out. According to Widayanti (2013), the analysis of student learning styles aims to make it easier to provide a learning environment that makes it easier and supports students in absorbing information maximally. Therefore, by knowing the various learning styles of these students, a design and development of learning media can be developed following the learning styles of each individual. Jambi.

Based on preliminary observations, it is known that the learning style analysis at SMAN 1 Muaro 
Table 4. Visual learning styles

\begin{tabular}{|c|c|c|c|}
\hline \multicolumn{4}{|c|}{ Visual Learning Styles } \\
\hline Interval & Category & Frequency & $\%$ \\
\hline $13.00-22.75$ & Very Never & 4 & 11.1 \\
\hline $22.76-32.50$ & Never & 6 & 16.7 \\
\hline $32.51-42.25$ & Often & 21 & 58.3 \\
\hline $42.26-52.00$ & Always & 5 & 13.9 \\
\hline
\end{tabular}

Table 4 explains that most of the SMAN 1 Muaro Jambi students have a visual learning style, with a percentage of $58.3 \%$ belonging to the frequent category. Thus, most students rely on hearing to both understand and remember learning.

Table 5. Kinesthetic learning styles

\begin{tabular}{|c|c|c|c|}
\hline \multicolumn{5}{|c|}{ Kinesthetic Learning Styles } \\
\hline Interval & Category & Frequency & $\%$ \\
\hline $15.00-26.25$ & Very Never & 4 & 11.1 \\
\hline $26.26-37.50$ & Never & 6 & 16.7 \\
\hline $37.51-48.75$ & Often & 21 & 58.3 \\
\hline $48.76-60.00$ & Always & 5 & 13.9 \\
\hline
\end{tabular}

Table 5 explains that SMAN 1 Muaro Jambi students have a kinesthetic learning style, with the highest percentage of $58.3 \%$ belonging to the frequent category. Thus, most students emphasize visual acuity in the learning process.

Table 6. Auditorial learning styles

\begin{tabular}{|c|c|c|c|}
\hline \multicolumn{5}{|c|}{ Editorial Learning Styles } \\
\hline Interval & Category & Frequency & $\%$ \\
\hline $14.00-24.50$ & Very Never & 2 & 5,6 \\
\hline $24.51-35.00$ & Never & 15 & 41.7 \\
\hline $35.10-45.50$ & Often & 19 & 52.8 \\
\hline $45.51-56.00$ & Always & 0 & 0 \\
\hline
\end{tabular}

Table 6 explains that SMAN 1 Muaro Jambi students have an auditory learning style with a percentage of $52.8 \%$ belonging to the frequent category. Thus, in the learning process, most students must touch something that provides specific information to remember it.

Based on the learning style questionnaire results, it can be concluded that students of SMAN 1 Muaro Jambi have visual, kinesthetic, and auditory learning styles. The results of this research are used as a reference in developing learning media with an approach that can support the student learning process. Based on the results, we know that all learning styles are suitable for implementing STEM learning. Then the application will be developed by using the three learning styles for visual learning style. There is a picture to help students understand the lesson; for kinesthetic learning style, there is an Experiment procedure to make something related to STEM. There is a video with visual and audio for the auditory learning style to help students understand the lesson. Learning media developed are tailored to the needs and characteristics of students. River in Nurseto (2012)reveals several benefits of learning media, including fostering student learning motivation because teaching makes students pay attention. The meaning of teaching materials will be more precise so that it can be understood. There is mastery and achievement of teaching goals, more varied teaching methods, and more students. Perform activities during learning activities. 
One of the learning support media or teaching materials that can be applied is using Student Worksheets in an android application. These student worksheets are prepared based on curriculum needs, and these student worksheets can be used anywhere and anytime by students. In addition, educators are also better off using a unique approach that follows the material needs of students, one of which is using the STEM approach. According to Permanasari (2016), STEM (Science, Technology, Engineering, and Mathematics) education is currently a science learning option that can uphold a generation capable of overcoming the challenging 21st century. Beers in Pertiwi (2017) also argues that STEM learning is an amalgamation of science, technology, engineering, and mathematics learning that is suggested to help advance 21 st-century skills.

By using the STEM approach in the learning media used, it is hoped that students will also have several skills as suggested by Suwarma et al. (2015), including:

1) Adaptability (skills to adapt to an unusual condition)

2) complex communication skills (skills in processing and interpreting information both verbally and nonverbally)

3) non-routine problem solving (desire to solve unusual problems)

4) self-management and self-development (ability to work automatically with groups or alone)

5) thinking system (the ability to understand the work of the entire system and understand how the effect of action change on the system).

The purpose of the STEM approach is to increase students' understanding of how something can work, increase the use of technology by students, and introduce engineering before going to college. Engineering is directly involved in problem solving and innovation. Students must learn about Engineering and develop skills and abilities following the Engineering Design Process (EDP) Prismasari et al., (2019). According to Kane et al. (2016), with performance appraisal in STEM education, we can assess each phase in the STEM approach. STEM indicators complement performance appraisal in order to assess science process skills. With indicators that are owned in the performance appraisal,

Thus, to provide an interactive, engaging, practical, learning media that can be used anytime and anywhere. At the same time, it is hoped that it can improve students' scientific literacy. A product is produced in the form of a STEM-based student worksheet application. Some of the product's advantages include the resulting product being an Android application for STEM-based Student Worksheets. This product has several advantages, namely; 1) The language is made easy to understand, 2) There are videos further to increase students' understanding of the learning material. Rasagama (2020) states that video is a type of learning media where the hearing and views of students can be interactive so that students can understand the content of knowledge material. 3) There are simple experiments that students at home / long distance can carry out, 4) There is a project making about material that is by the latest developments and is based on STEM.

\section{CONCLUSION}

This study seeks to find a study to analyze the needs of teachers and students for learning media or teaching materials. The results of this study are used to develop a learning media product in the form of STEM-based student worksheets. Teachers need interactive learning media that attract students' interest in learning and can be used by students in school. Based on these, we need STEM-based student worksheets in the Android Application so the student can use that everywhere, not only in school. From this research, we know that students have the learning style Visual, Kinesthetic, and Auditory. So we need to make learning media with visual, kinesthetic, and auditory learning styles. So the student can do the experimental practice about STEM everywhere and become easier to understand because of their learning style. Based on this, it can be used as a reference in the further development process, namely developing learning media in the form of STEM-based student worksheets. Products will be made in the form of an android application so that students can use it practically anywhere and anytime. Products will be made with a STEM approach to suit current technological developments and improve students' scientific literacy. 


\section{ACKNOWLEDGMENT}

Researchers would like to thank all those who have helped in completing this research. Thanks to the physics education study program at the University of Jambi, to the editor of the journal Science Education (JPS) UNIMUS, and also to the SMA N 1 Muaro Jambi school for allowing researchers to research so that it is carried out well and other suggestions that have been contributed to this research

\section{REFERENCES}

Alkadri, R., Yurnetti, \& Yohandri. (2017). Pembuatan Media Mobile Learning Berbasis Android untuk Mata Pelajaran Fisika Kelas XI SMA. Pillar of Physics Education, 10, 129-136.

Anggraini, F. I., \& Huzaifah, S. (2017). Implementasi STEM dalam pembelajaran IPA di Sekolah Menengah Pertama. Prosiding Seminar Nasional Pendidikan IPA 2017. STEM Untuk Pembelajaran Sains Abad 21. 23 September 2017, 1998, 722-731.

Endriani, R., Sundaryono, A., \& Elvia, R. (2018). Pengembangan media pembelajaran kimia menggunakan video untuk mengukur kemampuan berfikir kritis siswa. PENDIPA Journal of Science Education, 2(2), 142-146. https://doi.org/10.33369/pendipa.2.2.142-146

Gherardini, M. (2016). Pengaruh Metode Pembelajaran dan Kemampuan Berpikir Kritis Terhadap Kemampuan Literasi Sains. Jurnal Pendidikan Dasar, 7(2), 253-264.

Harefa, A. R. (2019). Peran Ilmu Fisika Dalam Kehidupan Sehari-hai. Jurnal Warta, 60, 91-96.

Permendikbud Nomor 81 A tahun 2013, Kemdikbud 1 (2014).

Lee, C.-D. (2014). Worksheet Usage, Reading Achievement, Classes' Lack of Readiness, and Science Achievement: A Cross-Country Comparison. International Journal of Education in Mathematics, Science and Technology, 2(2), 96-106. https://doi.org/10.18404/ijemst.38331

Nadiroh, S. M. F., \& Susilowibowo, J. (2018). Pengembangan Lembar Kegiatan Peserta Didik (LKPD) Berbasis Android Pada Mata Pelajaran Akuntansi Perbankan Syariah Kelas XI Perbankan Syariah Di SMK Negeri 1 Lamongan. Jurnal Pendidikan Akuntansi (JPAK), 6(3), 355-359.

Nurseto, T. (2012). Membuat Media Pembelajaran yang Menarik. Jurnal Ekonomi Dan Pendidikan, 8(1), 19-35. https://doi.org/10.21831/jep.v8i1.706

Pentury, H., Festiyed, Hamdi, \& Yurnetti. (2019). Pembuatan Lembar Kerja Peserta Didik (LKPD) Berbasis Model Discovery Learning Pada Materi Gelombang Berbantuan Aplikasi Android Untuk Kelas XI SMA/MA. Pillar of Physics Education, 12(4), 617-624.

Permanasari, A. (2016). STEM Education: Inovasi dalam Pembelajaran Sains. STEM Education: Inovasi Dalam Pembelajaran Sains, 23-34.

Pertiwi, R. S., Abdurrahman, \& Rosidin, U. (2017). Efektivitas LKS STEM untuk Melatih Keterampilan Berpikir Kreatif Siswa. Jurnal Pembelajaran Fisika, 5(2), 11-19.

Prismasari, D. I., Hartiwi, A., \& Indrawati. (2019). Science , Technology , Engineering and Mathematics ( Stem ) pada Pembelajaran IPA SMP. Seminar Nasional Pendidikan FIsika 2019 "Integrasi Pendidikan, Sains, Dan Teknologi Dalam Mengembangkan Budaya Ilmiah Di Era Revolusi Industri 4.0," 4(1), 43-45.

Rahmayani, F. (2019). Hubungan Antara Karakter Mandiri Belajar Dengan Hasil Belajar Siswa. JPE (Jurnal Pendidikan Edutama), 6(2), 87-94.

Rasagama, I. G. (2020). Pengembangan Model Pembelajaran Getaran Berbasis Video Youtube Untuk Meningkatkan Pemahaman Konsep Mahasiswa Politeknik. 8(2), 91-101.

Rusdi. (2018). Penelitian Desain dan Pengembangan Kependidikan(Konsep, Prosedur dan Sintesis Pengetahuan Baru). PT.Raja Grafindo Persada.

Sanders, B. M. (2009). Integrative STEM Education: Primer By. Integrative STEM Education: Primer, 68(4), 20-26.

Santana, D., Pratami, G., \& Sanjaya, H. (2019). Perancangan Animasi Interaktif untuk Bahan Ajar Mata Kuliah Biologi Berbasis Deskop Adobe Flash CS6 (Studi Kasus Prodi Pendidikan Biologi, FKIP, Universitas Majalengka). Prosiding SNST Ke-10 Tahun 2019 Fakultas Teknik Universitas Wahid Hasyim, 1(1), 287-292.

Septiani, A., \& Rustaman, N. Y. (2017). Preface: International Conference on Recent Trends in Physics (ICRTP 2016). Journal of Physics: Conference Series, 755(1). https://doi.org/10.1088/1742$6596 / 755 / 1 / 011001$

Sudarsana, I. K. (2016). Peningkatan Mutu Pendidikan Luar Sekolah Dalam Upayapembangunan Sumber https://jurnal.unimus.ac.id/index.php/JPKIMIA/index 
Daya Manusia. Jurnal Penjaminan Mutu, 1(1), 1. https://doi.org/10.25078/jpm.v1i1.34

Suwarma, I. R., Astuti, P., \& Endah, E. N. (2015). “Balloon Powered Car” Sebagai Media Pembelajaran Ipa Berbasis Stem (Science, Technology, Engineering, and Mathematics). Prosiding Simposium Nasional Inovasi Dan Pembelajaran Sains 2015, 2015(Snips), 373-376.

Walidin, W. (2016). Arah Pengembangan Sumber Daya Manusia Dalam Dimensi Pendidikan Islam. 2(June), 147-163.

Widayanti, F. D. (2013). Pentingnya Mengetahui Gaya Belajar Siswa Dalam Kegiatan Pembelajaran Di Kelas. Erudio Journal of Educational Innovation, 2(1). https://doi.org/10.18551/erudio.2-1.2 